\title{
“Dãolalalão" de Guimarães Rosa ou o "Cântico dos cânticos" do sertão: um sino e seu badaladal ${ }^{1}$
}

\author{
ADÉLIA BEZERRA DE MENESES
}

A NOVELA “Dãolalalão”, do livro Noites do sertão de Guimarães Rosa, mostra a presença daquilo que Northrop Frye nomeou o "Grande código" da literatura ocidental, a Bíblia, transculturada no sertão brasileiro, e as contradições daí advindas.

Com efeito, numa leitura estranhada e transgressiva do "Cântico dos cânticos", conta-se aí a história de um boiadeiro ex-matador de jagunços e de uma ex-prostituta, que ele tira do bordel para casar, e que viverão intensamente o "Amado" e a "Amada" desse poema de amor que é paradigma da lírica amorosa na literatura. No entanto, observe-se que em "Dãolalalão" não apenas o "Cântico" se faz presente: comparecem também paráfrases do "Apocalipse" e referências várias a Afrodite Pandêmia, deusa do amor no panteão grego, bem como ecos velados da prostituição sagrada.

Temos assim, concentrados nesse vértice bíblico-grego (à raiz da cultura ocidental), os elementos da literatura européia, "mimetizada" - ou, mais especificamente, modificada em contato com a cultura local. E, como procurarei apontar, marcada vincadamente por aquilo que é a mola da organização da sociedade brasileira: uma formação social de extração escravista.

Além disso, se é verdade que, ecoando a idéia de Bataille, "erotismo é transgressão", em "Dãolalalão" é esse paradigma que se imporá. Pois o viés da "transgressão" (que em termos literários poderá ser abordado por meio do "estranhamento") é levado ao limite nesse texto, bordejando o paradoxo, figura de estilo tão cara a Guimarães Rosa. Fiel à sua atitude básica diante da Palavra e da Vida, Guimarães Rosa transgride cânones estabelecidos para melhor penetrar no âmago da realidade; provoca estranhamento para que o objeto ressalte; subverte. Trata-se aqui do que Alfredo Bosi (1975) chama de uma "semântica do insólito".

"Dãolalalão" e "Buriti” podem ser considerados os mais sensuais dos textos de Guimarães Rosa. E não é gratuitamente que ambos fazem parte de Noites do sertão (Rosa, 1965a) - em que no vocábulo "noite" pode-se quase que ver um sinônimo de amor. Assim, em "Buriti", o narrador, referindo-se à dificuldade da existência de amor entre duas personagens, diz: "Era custoso aceitar-se que Dona-Dona algum dia tivesse acordado o desejo ou o amor de Nhô Gaspar, 
que os dois tivessem tido uma noite. Dona-Dona precisava da maior bondade do próximo, não era imaginável entre as belas grandes árvores, num jardim da banda do Oriente, num lugar de agrado" (grifos meus). Nesse trecho, além de "noite" como metonímia do amor e do desejo, nesse "jardim da banda do Oriente", "lugar de agrado", há a alusão inequívoca ao topos do locus amoenus, locus paradisiacus - lugar aprazível (“de agrado"), um Éden, que remete ao Jardim do "Gênesis" e ao Pardes (pomar), palavra persa de onde se origina "Paraíso" - e que é o espaço do amor e do encontro do casal humano, seja Adão e Eva no "Gênesis", seja o Amado e a Amada no "Cântico dos cânticos".

No "Cântico dos cânticos", o mais sensual livro da Bíblia e uma das realizações de mais alta poesia de todos os tempos - e que começa pelos célebres versos "Beija-me com beijos de tua boca / Teus amores são melhores do que o vinho / o odor dos teus perfumes é suave" -, celebra-se o amor de um Amado e de uma Amada, nomeados "Salomão" e "Sulamita". Influenciando fortemente toda a Erótica do Ocidente - não apenas a literatura, mas também a iconografia - resgatado pelos místicos e pela alquimia, o "Cântico" se tornou o arquétipo do encontro amoroso, da unificação dos contrários e da integração. Mas malgrado as interpretações alegorizantes que sofreu ao longo dos séculos, trata basicamente do amor de uma mulher e de um homem, amor erótico e pleno - talvez um cântico nupcial, de festa de casamento. Mas houve exegetas que atribuíram a autoria desse "Cântico" a Salomão (que, como se sabe, compôs cânticos) e, como é registrada na Bíblia, no "Livro dos reis", uma visita que lhe fez a rainha de Sabá, outra das interpretações correntes é a de que o "Cântico" celebre os amores da rainha de Sabá e do rei Salomão.

A aproximação de "Dãolalalão" com o "Cântico dos cânticos", ${ }^{3}$ por vezes quase que criptografada no texto, raras vezes explícita, foi revelada pelo próprio autor em correspondência com o seu tradutor italiano Edoardo Bizzarri. Diz Guimarães Rosa (2003, p.80), em carta de 1963: "Diluídas, aliás, nas páginas $537 / 540$ perpassa uma espécie de paráfrase do Cântico dos Cânticos”. E aí Guimarães Rosa elenca umas poucas passagens desse belíssimo poema bíblico e indica três páginas de "Dãolalalão", em que se teria verificado a "paráfrase". Suzy Sperber (1976, p.46-7), em Caos e cosmos publica em primeira mão esse trecho da carta, então inédita, de Bizzarri; e mais tarde, em Guimarães Rosa: signo e sentimento (Sperber, 1982, p.56-62), ela retornará a esse assunto, e, guiada por essas indicações de Guimarães Rosa, transcreve as frases (entre as tais páginas $537 / 540$ ) que ele assinalara, e confronta as formulações de um dos parágrafos de "Dãolalalão" com passagens do "Cântico". A pesquisadora se limita apenas ao que fora assinalado pelo autor, mas, como se verá, a influência do "Cântico" se revelará absolutamente determinante.

A imagem inicial com que se abre o conto é a do protagonista, Soropita, dominando sua montaria, ou melhor, administrando seu cavalo, que obedece ao mínimo achego da borda do pé do cavaleiro. Tal imagem não apenas figura como metáfora do domínio (sutil, mas implacável) do cavaleiro sobre a sua montaria, 


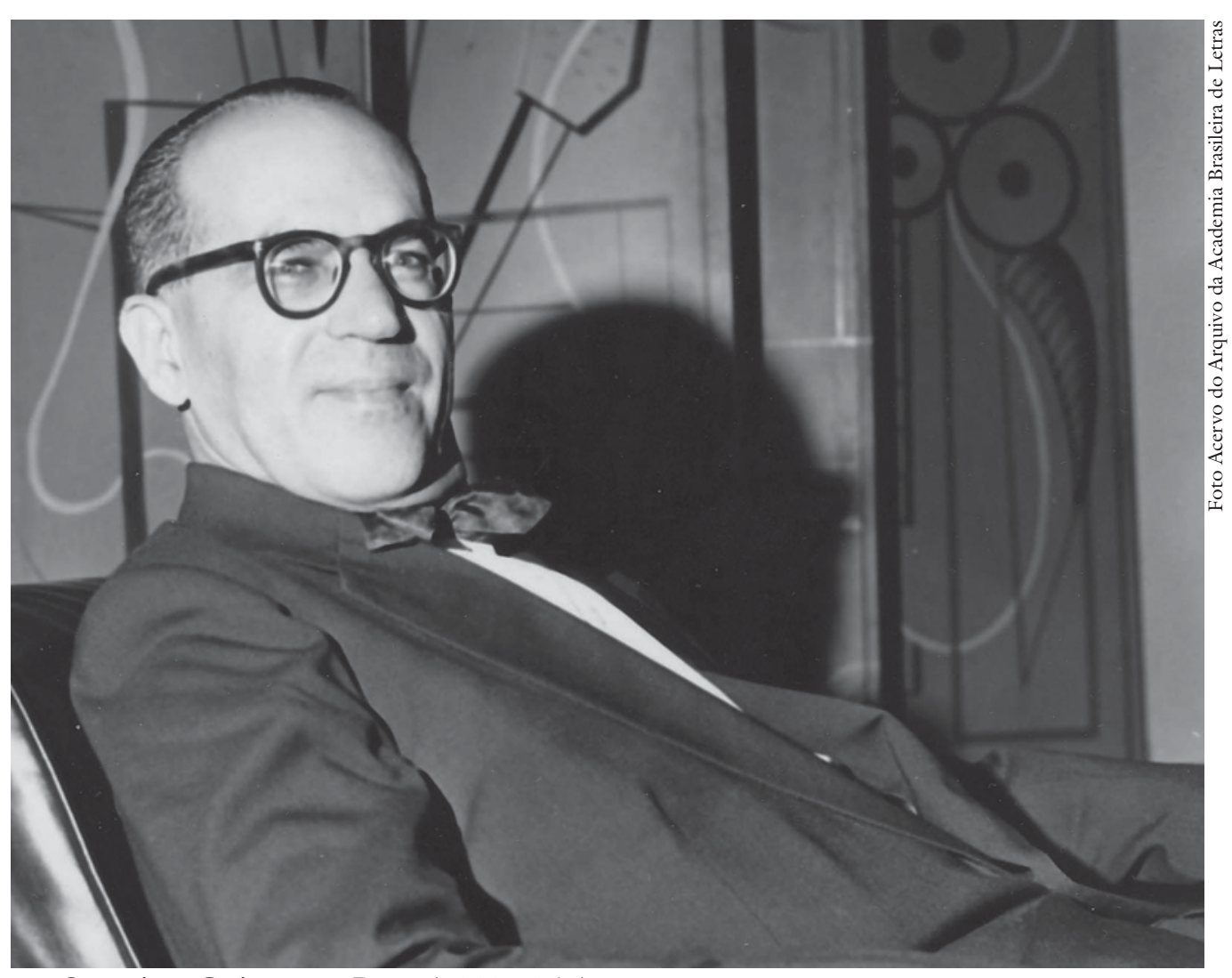

O escritor Guimarães Rosa (1908-1967).

mas já abre para o símile do relacionamento do casal de protagonistas. Efetivamente Doralda, ao ouvir o nome que o amigo de seu marido dera ao próprio cavalo, ou melhor, à mula rata que era sua montaria ("Nome dela é Môça Branca...”) (Rosa, 1965a, p.52)), dirá de si própria, apontando Soropita: "Eu é que sou a moça branca dele" (ibidem, p.59). Em pleno acordo com as idéias e fantasias do seu marido que, quando era ainda solteiro, assim "sobressonhava" sobre mulheres de um prostíbulo: "Que encontrasse de todas a melhor, e tirava-a dali, se ele gostasse, levar, casar, mesmo isso, se para a poder guardar tanto preciso fosse - garupa e laço, certo a certo" (ibidem, p.19). Por sua vez, a andadura do cavalo de Soropita, "bem balanceada, muito macia" (ibidem, p.5), também é aferida ao "empino bonito de caminhar" (ibidem, p.14) de Doralda. Mas é mais adiante que o símile é levado ao limite: "Doralda, aquela elegância de beleza: como a égua madrinha, total aos guizos, à frente de todas - andar tão ensinado de bonito, faceiro, chega a mostrar os cascos..." (ibidem, p.14). Essa inusitada comparação eqüina da mulher amada tem uma tradição lírica prestigiosa, na poesia oriental, e está presente no "Cântico dos cânticos" (1,9): "Minha amada, eu te comparo / À égua atrelada ao carro do Faraó!".

Um confronto do texto de "Dãolalalão" com o texto bíblico levaria ao seguinte quadro, em que se pode ver como a presença do "Cântico" permeará a narrativa de Guimarães Rosa inteirinha. 


\begin{tabular}{|c|c|}
\hline $\begin{array}{l}\text { "Cântico dos cânticos" } \\
(4,1-5)\end{array}$ & "Dãolalalão" \\
\hline $\begin{array}{l}\text { Como és bela, minha amada, } \\
\text { Como és bela! }\end{array}$ & Tu é bela... \\
\hline São pombas teus olhos escondidos sob o véu. & $\begin{array}{l}\text { O vôo e o arrulho dos olhos } \\
\text { O envesgo dos olhos. Só sutil, ela pombeava. }\end{array}$ \\
\hline Teu cabelo... um rebanho de cabras & Os cabelos, cabriol \\
\hline Ondulando pelas faldas de Gallaad. & A como as boiadas fogem no chapadão, nas chapadas... \\
\hline $\begin{array}{l}\text { Teus dentes ... um rebanho tosquiado } \\
\text { Subindo após o banho, } \\
\text { Cada ovelha com seus gêmeos, nenhuma delas } \\
\text { sem cria }\end{array}$ & $\begin{array}{l}\text { Os dentes, brancura de carneirinhos... } \\
\ldots \text { quando sorria mais, mostrava só a fila dos dentes de } \\
\text { cima, todos brancos que brilhavam. }\end{array}$ \\
\hline $\begin{array}{l}\text { Teus lábios são fita vermelha, } \\
\text { Tua fala melodiosa; }\end{array}$ & ... A boca-traço que tem a cor como as flores \\
\hline $\begin{array}{l}\text { Metade de romã são teus seios } \\
\text { Mergulhados sob o véu. }\end{array}$ & ... donde a romã das faces \\
\hline $\begin{array}{l}\text { Teu pescoço é a torre de Davi, } \\
\text { Construída com defesas; } \\
\text { Dela pendem mil escudos } \\
\text { E armaduras dos heróis. }\end{array}$ & $\begin{array}{l}\text { O pescoço, no colar, para se querer com sinos e altos, de } \\
\text { se variar de ver }\end{array}$ \\
\hline $\begin{array}{l}\text { Teus peitos são filhotes gêmeos de } \\
\text { gazela, pastando entre as açucenas, }\end{array}$ & Os seios mal se passavam no ar \\
\hline $\begin{array}{l}\text { Antes que sopre a brisa e as sombras } \\
\text { Se debandem, }\end{array}$ & \\
\hline $\begin{array}{l}\text { Vou ao monte da mirra, } \\
\text { E à colina do incenso. }\end{array}$ & Doralda - deixava seu perfume se fazer. \\
\hline $\begin{array}{l}(1,2) \\
\text { Beija-me com os beijos de tua boca! }\end{array}$ & $\begin{array}{l}\text { "De vez tu não me abraça e beija, Bem? Tu não quer"? } \\
\text { (ibidem, p.66) }\end{array}$ \\
\hline $\begin{array}{l}\text { Teus amores são melhores do que o vinho, } \\
\text { O odor de teus perfumes é suave, }\end{array}$ & $\begin{array}{l}\text { "Tu é a bebida do vinho..." (ibidem, p.67) } \\
\text { Você é o estado dum perfume. Respirar que forma uma } \\
\text { alegria... }\end{array}$ \\
\hline Teu nome é como um óleo escorrendo & $\begin{array}{l}\text { Até o nome de Doralda, parece que dá um prazo de } \\
\text { perfume. (ibidem, p.66). }\end{array}$ \\
\hline $\mathrm{E}$ as donzelas se enamoram de ti. $(1,2-3)$ & "Todo mundo gostava de você..." (ibidem, p. 67) \\
\hline $\begin{array}{l}\text { Sou negra, mas formosa, } \\
\text { Ó filhas de Jerusalém } \\
\text { Não olheis eu ser morena: } \\
\text { Foi o sol que me queimou: } \\
\text {... }\end{array}$ & $\begin{array}{l}\text { "Nega, ela não ficara feia, por no muito amor desusar } \\
\text { sua virtude" (ibidem, p. 67) }\end{array}$ \\
\hline $\begin{array}{l}\text { Avisa-me, amado da minha alma, } \\
\text { Onde apascentas, onde descansas } \\
\text { O rebanho ao meio-dia } \\
\text { Para que eu não vague perdida } \\
\text { Entre os rebanhos de teus companheiros }\end{array}$ & $\begin{array}{l}\text { Ah, uma pode errar de boiada, por ir-se atrás de } \\
\text { boiadeiro... (ibidem, p.67) }\end{array}$ \\
\hline $\begin{array}{l}\text { Se não o sabes, } \\
\text { Ó mais bela das mulheres, }\end{array}$ & $\begin{array}{l}\text { "Tu é a melhor, a mais merecida de todas..." (ibidem, } \\
\text { p.69) }\end{array}$ \\
\hline Segue o rastro das ovelhas. & $\begin{array}{l}\text { Se tu me chamasse, Bem, eu era capaz de vir a pé, } \\
\text { seguindo o rastro de teus bois. (ibidem, p.77) }\end{array}$ \\
\hline
\end{tabular}




\begin{tabular}{|c|c|}
\hline $\begin{array}{l}\text { Minha amada, eu te comparo } \\
\text { à égua atrelada ao carro do Faraó }(1,9)\end{array}$ & $\begin{array}{l}\text { "Doralda, aquela elegância de beleza: como a égua } \\
\text { madrinha, total aos guizos, à frente de todas - andar tão } \\
\text { ensinado de bonito, faceiro, chega a mostrar os } \\
\text { cascos..." (ibidem, p.14) } \\
\text { "Apelido que esse vaqueiro dava a ela era de a } \\
\text { Garanhã..." (ibidem, p.55) }\end{array}$ \\
\hline \multicolumn{2}{|l|}{$(2,2 ; 7)$} \\
\hline $\begin{array}{l}\text { Como açucena entre espinhos } \\
\text { É minha amada entre as donzelas } \\
\text {... }\end{array}$ & "Mas mais me chamavam de Sucena". (ibidem, p.67) \\
\hline $\begin{array}{l}\text { Filhas de Jerusalém, } \\
\text { Pelas cervas e gazelas do campo, } \\
\text { Eu vos conjuro: } \\
\text { Não desperteis, não acordeis o amor, } \\
\text { Até que ele o queira }\end{array}$ & "Veada.... Vaquinha" \\
\hline $\begin{array}{l}\text {... e o canto da rola } \\
\text { Está-se ouvindo em nosso campo } \\
\ldots\end{array}$ & "As rolinhas ainda arrulhavam? (ibidem, p.46) \\
\hline ... as mandrágoras exalam seu perfume & $\begin{array}{l}\text { O jasmim-verde e o jasmim-azul, obrigavam tudo com } \\
\text { seu perfume - que dava para adoçar uma xícara de café. }\end{array}$ \\
\hline $\begin{array}{l}(2,16) \\
\text { Meu amado é meu e eu sou dele, }\end{array}$ & $\begin{array}{l}\text { "Soropita em soberbas se alegrando: de ver a que ponto } \\
\text { Doralda queria que o Dalberto notasse o quanto ela } \\
\text { dele e ele dela se gostavam." }\end{array}$ \\
\hline Do pastor das açucenas! & $\begin{array}{l}\text { "Sucena? A Sucena? Mas, essa?! Ah, pois conheço, Bem. } \\
\text { Conheço inteira: é da gandaia! (ibidem, p.24) }\end{array}$ \\
\hline $\begin{array}{l}(5,8) \\
\text { Dizei que estou doente de amor! }\end{array}$ & Bem, eu estou adoecida de amor..." (ibidem, p.76 \\
\hline $\begin{array}{l}(4,7) \\
\text { És toda bela, minha amada, } \\
\text { E não tens um só defeito! }\end{array}$ & $\begin{array}{l}\text { "Doralda, a mais bela - mimosa sem candura" (ibidem, } \\
\text { p.65) }\end{array}$ \\
\hline $\begin{array}{l}(4,10-11) \\
\text { Teus amores são melhores do que o vinho, }\end{array}$ & "Tu é a bebida do vinho!" \\
\hline $\begin{array}{l}\text { Mais fino que os outros aromas } \\
\text { É o odor dos teus perfumes. }\end{array}$ & $\begin{array}{l}\text { "Do cheiro mesmo, de Doralda, ele gostava por demais, } \\
\text { um cheiro que ao breve lembrava sassafrás, a rosa } \\
\text { mogorim e palha de milho viçoso: e que se pegava , só } \\
\text { assim, no lençol, no cabeção, no vestido, nos } \\
\text { travesseiros. Seu pescoço cheirava a menino novo. Ela } \\
\text { punha casa-boa e manjericão miúdo na roupa lavada, } \\
\text { para exalar, e gastava vidro de perfume. [...] Tinha } \\
\text { ouvido contar da casca da cabriúva: um almíscar tão } \\
\text { forte, bebente, encantável, que os bichos, galheiro, } \\
\text { porco-do-mato, onça, vinham todos se esfregar na } \\
\text { árvore, no pé." }\end{array}$ \\
\hline Teus lábios são favo escorrendo, & $\begin{array}{l}\text { "Que é o mel branco, damice de mulher, hem } \\
\text { Surupita?" (ibidem, p.41) }\end{array}$ \\
\hline $\begin{array}{l}\text { Ó noiva minha, } \\
\text { Tens leite e mel sob a língua, }\end{array}$ & $\begin{array}{l}\text { "Cocaína, meu Bem. Experimentei só uma vez, só umas } \\
\text { duas vezinhas... [...] A gente provar, Bem, e eu te beijar } \\
\text { tua língua, em estranho, feito um gelo...." (ibidem, } \\
\text { p.13) }\end{array}$ \\
\hline
\end{tabular}




\begin{tabular}{|c|c|}
\hline $\begin{array}{l}\text { E o perfume de tuas roupas } \\
\text { É como a fragrância do Líbano. }\end{array}$ & $\begin{array}{l}\text { Um dia, Soropita levou a Andrequicé um vestido dela, } \\
\text { tirado do corpo, para servir de amostra. Dormiu } \\
\text { abraçado com ele - o vestido durava o cheiro dela, nas } \\
\text { partes, nas cavas das mangas - Soropita enrolara-o no } \\
\text { rosto, queira consumir a ação daquele cheiro, até no } \\
\text { fundo de si, com força, até o derradeiro grão de exalo." } \\
\text { (ibidem, p.14-15) }\end{array}$ \\
\hline $\begin{array}{l}(4,12-14) \\
\text { És jardim fechado, } \\
\text { Minha irmã, noiva minha, } \\
\text { És jardim fechado, }\end{array}$ & $\begin{array}{l}\text { "A casa, com as janelas abertas. A paineira era uma rosa } \\
\text { enorme". (ibidem, p.46) }\end{array}$ \\
\hline Uma fonte lacrada. & $\begin{array}{l}\text { "Soropita, achei uma mulher que é um durame de } \\
\text { delícia. } \\
\text { É uma cuia de água limpa..." }\end{array}$ \\
\hline \multicolumn{2}{|l|}{$\begin{array}{l}\text { Teus brotos são pomar de romãs } \\
\text { Com frutos preciosos: }\end{array}$} \\
\hline $\begin{array}{l}\text { Nardo e açafrão, canela, cinamomo, } \\
\text { E árvores todas de incenso, mirra e aloés, } \\
\text { E os mais finos perfumes. }\end{array}$ & $\begin{array}{l}{[\ldots] \text { : “Queimava alecrim, caatinguá, cipó-de-sempre, no }} \\
\text { quarto, de noite, antes de irem se deitar. Quassava a } \\
\text { chegadinha, para borrifar na roupa de cama, ou para } \\
\text { fumigar.Outra ocasião, encomendava pitada de incenso } \\
\text { ou resinas de breu branco, que oficiava de arder em } \\
\text { todos os cômodos a levar do ar os quebrantos, qualquer } \\
\text { pêgo de má-sorte; a casa almiscrava que nem igrejas ...” }\end{array}$ \\
\hline $\begin{array}{l}\text { A fonte do jardim } \\
\text { É poço de água viva } \\
\text { Que jorra, descendo do Líbano! }\end{array}$ & $\begin{array}{l}\text { "Doralda era um consolo. Uma água de serra - que } \\
\text { brota, canta e cai partida: bela, boa e oferecida." } \\
\text { (ibidem, p.43) }\end{array}$ \\
\hline \multicolumn{2}{|l|}{$(5)$} \\
\hline \multicolumn{2}{|l|}{$\begin{array}{l}\text { "Abre, minha irmã, minha amada, } \\
\text { Pomba minha sem defeito! }\end{array}$} \\
\hline $\begin{array}{l}\text { Meu amado põe a mão pela fenda da porta: } \\
\text { As entranhas me estremecem, } \\
\text { Minha alma, ouvindo-o se esvai! }\end{array}$ & “Tu põe a mão em mim, eu arrupeio toda." \\
\hline$(7,1)$ Volta-te, volta-te, Sulamita & "Vira para cá. Não, fica aí mesmo, onde você estava... \\
\hline Queremos te contemplar! & $\begin{array}{l}\text { "agora, caminha, quero te ver mais, o que não canso - } \\
\text { caminha, pra mim..." (ibidem, p.67) }\end{array}$ \\
\hline
\end{tabular}

Como se vê - e como já referi - muito para além do que o autor indica como influência do "Cântico" no seu conto, há uma impregnação fortíssima desse texto bíblico em "Dãolalalão", em clave de estranhamento.

Talvez o estranhamento mais estridente seja ter transformado a Amada bíblica numa ex-prostituta. É o caso de se perguntar: por que prostituta? Por que essa presença tão marcante da meretriz na ficção de Guimarães Rosa? Mulheres (com M maiúsculo!) que sempre "estavam na alegria, esperando". Paradigma da generosidade, e da dádiva, a mulher-prostituta em "Dãolalalão" é comparada a uma "cuia de água limpa", e o bordel, a um "paraíso de Deus, o pasto e a aguada do boiadeiro" (ibidem, p.18), numa total ausência de qualquer percepção de pecado, de malícia. Diz Marcuse (1968, p.XVII) que "a moralidade castradora da civilização interditou de tal maneira o uso do corpo como instrumento de prazer, que esse uso se manteve como 'infeliz privilégio' de prostitutas, degra- 
dados e pervertidos". Nos contos de Guimarães Rosa, esse é um privilégio das mulheres dadivosas que são as prostitutas, mas não propriamente um privilégio “infeliz". E se Doralda, ao se apaixonar por Soropita, não hesitou em deixar o bordel para acompanhá-lo, também nunca renegou sua atividade pregressa, reconhecendo que gostava do que fazia: “- Gostava, uai. Não gostasse, não estava lá... (Rosa, 1965a, p.68). E, para mortificação do marido, orgulhava-se do reconhecimento de sua competência como mulher-dama das mais apreciadas e procuradas: "quem ia comigo uma vez, sempre que podia sempre voltava... Nunca fizeram pouco em mim. Diziam que eu tinha condão..." (ibidem, p.68). Doralda e sua sexualidade radiosa e desreprimida.

Em "Estória de Lélio e Lina", de Corpo de baile, uma personagem diz que "Nosso Senhor, enquanto esteve cá embaixo, fez uma santa.Vigia que essa não foi uma puras-virgens, moças-de-família, nem uma masteira senhora-de-casa, farta-virtude. Ah, aí, aí não: a que soube se fazer, a que Ele reconheceu, foi uma que tinha sido dos bons gostos - Maria Madalena...”. Talvez seja por isso que Guimarães Rosa tenha colocado o conto "Dãolalalão", que trata de prostitutas, à luz do "Cântico dos cânticos", paradigma de uma relação amorosa arquetípica. Vemos aí transgressão, desautomatização, subversão - e uma fina percepção do que é cantado no "Cântico": o amor na sua plenitude, o amor entre o homem e a mulher não seria primordialmente um amor conjugal visando à procriação. É o que surpreendentemente diz uma avó sertaneja, personagem de outro conto de Noites do sertão, "Buriti” (Rosa, 1965b, p.159-60), a Vovó Maurícia, falando de criar filhos: "Mas a gente se casa não é só para isso, não - a gente se casa será é para lua-de-mel, luas-de-méis!".

E a prostituta na ficção de Rosa canalizará todo seu saber de fêmea, testado com muitos, para um só, o seu amado, o escolhido. Mas ela também não procria, não tem filhos. É interessante que em "Dãolalalão" não se ressalta a questão da venalidade ("venal": da mesma raiz de "vender"), do pagamento, do comércio do corpo. Nem o fator socioeconômico é convocado para explicar a escolha profissional daquelas mulheres, mas sim seu gosto por homens, e sua característica de "dadivosas". Diz Riobaldo, em Grande sertão: veredas: "Bom quando há leal, é amor de militriz...".

Discorrendo sobre o "mundo de belas coisas que se passam num bordel", refere-se o narrador a "mulheres assim leves assim, dessôltas, sem agarro de família, sem mistura com as necessidades dos dias, sem os trabalhos nem dificuldades: eram que nem pássaros de variado canto e muitas cores, que a gente está sempre no poder de ir encontrando, sem mais, um depois do outro, nas altas árvores do mato, no perdido coração do mundo" (Rosa, 1965a, p.24). Em resumo: puro princípio de prazer, recusa ao princípio de realidade.

Há passagens que em "Dãolalalão" se fala do encontro masculino-feminino (sempre com uma prostituta!), das mais belas da nossa literatura. Como a opinião de Soropita: "Tudo no diário disformava aborrecido e espalhado, sujo, 
triste, trabalhos e cuidados, desgraceiras e medo de tanta surpresa má, tudo virava um cansaço. Até que homem se recomeçava junto com mulher, força de fogo tornando a reunir seus pedaços, o em-deus!" (ibidem, p.21).

A experiência do encontro é, assim, um recomeçar, uma possibilidade de energização e de reunificação de si. E mais adiante, sentencia Dalberto, outro que se apaixonou por uma prostituta, e que também planeja retirá-la do bordel:

só quando se está com mulher é que a gente sente mesmo que está lorde, com todos os perdões... que é que se está vivendo, mesmo. Afora isso, tudo é poeira e palha, casca miúda. A gente vai indo, caçoando e questionando, agenciando, bazofiando, tendo medo, compra isto, vende aquilo. Como que na gente deram corda. Homem não se pertence. Mas, um chegou, viu mulher, acabou-se o pior. Começa tudo, se tem nova coragem... (ibidem, p.36)

Dessa perspectiva é que se pode interpretar o nome da dona do bordel que eles freqüentavam, em Montes Claros, a "Casa da Clema". Clema: corruptela de Clementina, do latim Clemens, clementis = clemente, bom, indulgente, doce. E Clementia = bondade, doçura, e também "humanidade". ${ }^{4}$

A valorização que Guimarães Rosa empreende da prostituta encaminha-a, no entanto, muito mais para o nível do mito do que o da história. Nenhuma visada socioeconômica do fenômeno da prostituição que, aqui, quase que se vincula à prostituição sagrada. Sacerdotisas de uma Afrodite Pandêmia, trata-se de mulheres votadas ao amor. Efetivamente, no Banquete de Platão, há referências a duas Afrodites: a Urânia, divindade do amor celeste, idealizado, e a Afrodite Pandêmia (de "todo o povo"), do amor carnal, do prazer, que seria a padroeira de Doralda e da Analma, as amadas de Soropita e Dalberto, respectivamente. (Num parêntese: é verdade que Doralda faz o percurso de uma Afrodite-detodos para a Afrodite Urânia, quando elege Soropita como seu amado.) Mas, surpreendentemente, a reflexão de Soropita sobre os bordéis não permanece só positiva. Inesperadamente, ele desmitifica o mundo dos prostíbulos:

o cismo, de supetão, de ser, vindo no real, tudo por contrário. De simples, todo mundo farto sabia o que tinha também de nojento naquelas casas de bordel: brigas, corrumaca de doenças, ladroagem, falta de caráter. Alguém queria saber de sua mãe ali, sua filha, suas irmãs? Muitas mulheres mentiam... (ibidem, p.38)

Por que, porém, pergunta ele, “só se guardava na lembrança o que rebrilha de engraçado e fino bom...?”. Esse viés negativo e inquietante na valorização da prostituta se reforçará na "visão" que Soropita tem de Doralda, quando ela, de vestido chique, salto alto, cinto, pó de arroz e carmim se exibe para o marido (que tem algo de um voyeur) e para o hóspede Dalberto:

Sobre de pé, no meio da sala, era uma visão: Doralda vestida de vermelho em cima das Sete Serras, recoberta de muitas jóias, que retiniam, muitas pérolas, ouros, copo na mão, copo de vinhos e ela como se esmiasse e latisse, anéis de ouro naquelas especiosas mãos, por tanto sugiladas tanto, Doralda vinha monta- 
da numa mula vermelha, se sentar nua na beira das águas da Lagoa da Laóla, ela estava bêbada; e em volta aqueles sujeitos valentões, todos mortos, ele Soropita aqueles corpos não queria ver... (ibidem, p.59)

Com essa visão, quase que uma alucinação de Soropita, repito, o viés inquietante, com seu rastro de morte, se imporá. Também para esse texto se encontrará uma referência bíblica - a saber, o "Apocalipse" (17,1-7), o trecho denominado "A Grande Prostituta", que cito textualmente para cotejo, e em que a abominação é inequívoca:

Um dos Anjos das sete taças veio dizer-me: "Vem! Vou mostrar-te o julgamento da grande Prostituta que está sentada à beira de águas copiosas: os reis da terra se prostituíram com ela, e com o vinho da sua prostituição embriagaram-se os habitantes da terra." Ele me transportou então, em espírito, ao deserto, onde vi uma mulher sentada sobre uma Besta escarlate cheia de títulos blasfemos, com sete cabeças e dez chifres. A mulher estava vestida com púrpura e escarlate, adornada de ouro, pedras preciosas e pérolas; e tinha na mão um cálice de ouro cheio de abominações; são as impurezas da sua prostituição. Sobre a sua fronte estava escrito um nome, um mistério: "Babilônia, a Grande, a mãe das prostitutas e das abominações da terra." Vi então que a mulher estava embriagada com o sangue dos santos e com o sangue das testemunhas...

Eu havia, porém, falado que a relação de "Dãolalalão" com o "Cântico" seria em clave de estranhamento. E na costumeira maneira de Guimarães Rosa, há um "estranhamento do estranhamento". Com efeito, nessa leitura estranhada que Guimarães Rosa faz do "Cântico dos cânticos", recusando-se a uma inversão pura e simples, em que a prostituta "redimida" encarnaria o mais puro amor, e em que o ex-jagunço encontraria a paz e a plenitude nesse encontro, vemos um Soropita às voltas com ciúmes, pressentimentos e ânsias, pronto a matar, e com uma sexualidade complicada, assaltado por uma angústia fusional, chegado a um voyeurismo e, sobretudo, deixando-se atrair exclusivamente por prostitutas. Atração pela meretriz: a mulher de muitos, a mulher partilhada. Mesmo quando devaneia, mesmo quando fantasia, é com prostitutas; sabemos, além disso, que Soropita, quando solteiro, planejara casar-se com uma delas, a melhor. E nas suas atuais fantasias, excita-se mesmo quando tem uma mulher partilhada com outro. O instigante é que esse mesmo esquema se repete, tal e qual, com o seu melhor amigo, Dalberto, que se apaixona por uma prostituta a quem pretende tirar do bordel. "Dizia que era filha de família, lida demais, toda nova, e fugiu para a vida maior", "por de homens muito gostar"... Dalberto narra a Surupita que a sua prostituta, a Analma (o nome é significativo!) lhe conta das "coisas feias" pelas quais ela, sua noivinha, tem que passar com aqueles que pagam "por sua regalia completa". E Dalberto se dá conta de que ela se alegrava com o que falava, e conclui, com uma incrível percepção: "Mas tem horas, que eu penso que quem-sabe é pelo quindim dessas meias-doidices, mesmo, Soropita, que ela não sai da cabeça minha, que é mais um sabor...”. Ambos os amigos experimentam algo em comum: para o gozo, a mulher tem que ser partilhada - por mais 
que seu ciúme fique acirrado, ou, talvez, por isso mesmo. E o senso da posse - "garupa e laço, certo a certo"; "E macho homem é quem está por cima de qualquer vantagem...” (ibidem, p.56) - é determinante.

Instaura-se assim um contraste violento, conflitante, entre, de um lado, a beleza do amor declarado de Soropita e Doralda - sob o paradigma do "Cântico dos cânticos" (em que impera a plena reciprocidade) e, de outro, o desconcerto desse amor e sua ambigüidade. Pois, além de tudo isso, pelo menos em três vezes, insinua-se no relacionamento de Soropita com sua mulher uma pérfida possibilidade de traição, por parte dela. Com efeito, bem no início do conto, relata o narrador: "Doralda então ficava brincando de olhar para ele sem piscar, jogando ao sério: os olhos marrons, molhavam lume os olhos. Nesses brejos maiores de vereda, e nos corguinhos e lagoas muito limpas, sucuri mora" (ibidem, p.8). Há uma inequívoca aproximação dos olhos marrons de Doralda, de úmido brilho, com os brejos onde mora a serpente. É certo que quem fala isso é o narrador, e o narrador, aqui, é "indigno de confiança”. Essa mesma estranheza inquietante se repetirá ao fim do conto. Após uma descrição da amada - que partindo do sexo chega aos olhos -, diz o texto: "Soropita, um pensamento ainda por ele passou, uma visão: mais mesmo no profundo daqueles olhos, alguém ria dele" (ibidem, p.69). Reponta, assim, no meio da mais intensa paixão do protagonista por sua amada, a possibilidade, sempre presente, de um logro, de um dolo. Em outro momento, quase ao chegar em casa, acompanhado de Dalberto, suado e desconfortado, Soropita pensa na mulher: "Doralda era um consolo. Uma água de serra - que brota, canta e cai partida: bela, boa e oferecida". Toda a ambigüidade embutida nesse "oferecida", em se tratando de Doralda, num certo sentido se vê justificada e reforçada pela passagem contígua que alude a um "rastro de cobra, seu regozinho contornado na poeira, no descer para a grota". De novo, o contraponto das maravilhas de sua relação com a mulher, e a figura soturna e simbólica da cobra.

Os nomes de Doralda se prestam a essa ambigüidade. Vejamos seus apelidos: Dola (como a mãe a chamava); e seus nomes profissionais: Sucena, Dadã e Garanhã.

Sucena - Açucena é a flor presente no "Cântico dos cânticos" - é o lírio branco, símbolo da eleição do objeto amado, símbolo também da pureza. "Como o lírio entre os cardos, assim minha bem-amada entre as jovens mulheres" (Ct., I,2). Mas também Sucena, como nome de guerra da prostituta, da mesma raiz do francês "sucer", nos remeteria a uma direção completamente diferente. De sua Doralda, Soropita dirá que ela era "mimosa sem candura" (Rosa, 1965a, p.65). Garanhã - aludindo à energia sexual de Doralda, também vai ser aferida à "égua" do início do conto e também presente no "Cântico dos cânticos", como já vimos. Dadã, que pode ser decodificado como uma espécie de aumentativo daquela que "dá", paradoxalmente nos remeterá ao "Cântico dos cânticos", via rainha de Sabá. Pois Dadã é um termo que aparece na Bíblia, é o nome de uma colônia árabe que, na Bíblia, sempre vem mencionada junto com Sabá (I Reis, 
10,1-13). ${ }^{5}$ E Dola - o nome com que a mãe a chamava: remete ao grego dolo, que significa fraude, insídia, traição. Será essa a grande ruptura: inserir no poema de amor arquetípico uma cunha de traição. Como sempre, em Guimarães Rosa, o Bem e o Mal entranhados, pactados. A realidade é complexa demais para se deixar aprisionar na fórmula "feliz em anjos de ouro no casamento": por que Soropita queria mudar-se para o Campo Frio, longe de vizinhos e de olhares?

Do quadro anterior que estabeleceu o cotejo entre o texto bíblico e o conto de Guimarães Rosa, o que importará não é uma “adaptação" apelando para brasileirismos e sertanismos, em que se traduz uma realidade (no caso, oriental, bíblica) por sua versão tropicalizada, como é o caso das "boiadas nos chapadões", substituindo as "cabras descendo as montanhas de Galaad", ou os jasmins cujo perfume "dava para adoçar uma xícara de café" no lugar das "mandrágoras que exalam seu perfume". E nem mesmo o que importa é a ruptura do paradigma escolhido, que é radicalmente transgredido pelas personagens que figuram o Amado e a Amada do "Cântico". Com efeito, Soropita guarda do passado o impulso ao crime; Doralda mantém de sua vida pregressa tendências, gostos e antigos hábitos que destoariam do quotidiano acomodado e caseiro daquele povoado do Ão: o gosto para as bebidas fortes, o cigarro, e sobretudo a cocaína; e um certo desconcertante "dar-se" a olhares masculinos, cujo efeito ela compensa pelo apego que demonstra ao marido. (E tudo se redime no momento em que usa de todo o seu saber erótico profissional no relacionamento com Soropita seu eleito, o escolhido.) Compare-se, assim, o "jardim fechado" dos versos do "Cântico" (4,12-14): à casa "com as janelas abertas" de "Dãolalalão"; ou então a "fonte lacrada", água interdita, aferida à Sulamita, com a oferta plena da "cuia de água limpa" e, sobretudo, com a "água de serra - que brota, canta e cai partida: bela, boa e oferecida", aferida à mulher, na novela de Guimarães Rosa.

Não está aí, no entanto, a grande alteração. Observa-se - e isso é o mais importante - um elemento estranhado e disruptor, que só poderia irromper num contexto social como o da sociedade brasileira. E para tanto, vou pegar um detalhe, um elemento aparentemente secundário, mas que se revestirá de uma importância extrema na trama narrativa de Guimarães Rosa: o tópos do cheiro, que tanto caracteriza Doralda. Mas tanto num como noutro texto (em que o erotismo se faz intenso), esse é um componente importantíssimo. (Não por acaso, aliás, é o olfato o mais primitivo dos sentidos; conhece-se sua importância na esfera sexual, o inebriamento, a ação dos feronômios etc.). A esse propósito, eu já havia referido antes que na Bíblia, no "Livro dos reis", registra-se uma visita da rainha de Sabá a Salomão. Pois bem, o que é que a rainha oferece como presente ao rei? Vejamos o texto de II Reis (1-3;10-13):

A rainha de Sabá ouviu falar da fama de Salomão e veio pô-lo à prova por meio de enigmas. Chegou a Jerusalém com numerosa comitiva, com camelos carregados de aromas, grande quantidade de ouro e de pedras preciosas. [...] A rainha de Sabá trouxera ao rei Salomão uma tal abundância de aromas, que jamais se viu em tanta quantidade. 
$\mathrm{Na}$ economia das inversões e do estranhamento (estilístico, de enredo, de situações) operada pela prosa ficcional de Guimarães Rosa (1965a) em "Dãolalalão", Soropita dá à sua rainha sertaneja um presente: no alforje, bem afivelado e seguro, "ali dentro, trazia para a mulher o presente que a ele mais prazia: um sabonete cheiroso, sabonete fino, cor de rosa" (ibidem, p.9). Esse sabonete corde-rosa é uma espécie de quintessência de todos aqueles perfumes presentes no "Cântico".

E se no "Cântico" $(1,3)$ a Amada fala: "o odor dos teus perfumes é suave, /Teu nome é como um óleo escorrendo", no texto de Guimarães Rosa diz o Soropita: "Você é o estado dum perfume. [...] Até o nome de Doralda, parece que dá um prazo de perfume". Com efeito, a caracterização mais marcada de Doralda é o riso e é o cheiro - não apenas o seu cheiro feminino, tão intensamente referido pelo marido; há no conto um verdadeiro "tratado" sobre os odores sertanejos, correspondendo à presença intensa dos perfumes do "Cântico", como pudemos ver no cotejo "Cântico" / "Dãolalalão".

Também aqui, o mais importante não é a tradução dos cheiros orientais ("nardo e açafrão, canela, cinamomo / e árvores todas de incenso, / mirra e aloés, / e os mais finos perfumes") pelos cheiros tropicais ("sassafrás, rosa mogorim e palha de milho viçoso; casca-boa e manjericão miúdo; casca da cabriúva; alecrim, caatinguá; resinas de breu branco..."). Com efeito, a apropriação do "Cântico dos cânticos" que se verifica no texto roseano não se dá somente, repito, no nível do pitoresco, com o "gosto pela expressão local”, pelos brasilianismos e pelas particularidades sertanejas.

Efetivamente, se continuarmos a nos debruçar sobre esse extremamente significativo topos dos cheiros em "Dãolalalão", nos daremos conta de que, contrapondo-se ao cheiro que atrai Soropita para o amor, há o cheiro que o impele ao ódio: a “catinga” do negro Iládio, que logo de início é animalizado por meio de sua "morrinha", de um "almíscar ardido", aferido ao cheiro de sangue da codorniz estraçalhada.

Deixemos, porém, (ainda!) por mais uns instantes essa questão em suspenso. Vou retornar ao enredo e à caracterização com que as personagens aparecem no conto.

Se Doralda é caracterizada pelos atributos da mulher muito fêmea, pelo cheiro e pelo riso ${ }^{6}$ (de "quente colorido, qual, que é do riso de mulher muito mulher: que não se separa do todo da pessoa, antes parece chamar tudo para dentro de si"), de Soropita a primeira coisa que é descrita, com vagar e capricho, são suas armas metonímicas (e simbólicas). Com efeito, matador de muitas mortes, Soropita carregava no próprio corpo as marcas do seu passado, suas muitas cicatrizes. Ele e sua mulher teriam, ambos, um passado a ocultar.

O conto se tece das divagações de Soropita ao longo da viagem que ele faz, costumeiramente, do povoado onde mora à cidadezinha de Andrequicé, divagações que o reportarão ao passado, e por meio das quais ficamos sabendo 
de Doralda. É um "sobressonhar", “prazer de sombra”, em que ele fantasia suas (dele, Soropita) aventuras passadas nos bordéis. Numa dessas viagens, encontra um velho amigo, Dalberto, que lhe conta estar enamorado de uma prostituta, que quer tirar do bordel para viverem juntos. O susto de Soropita é enorme, ele teme que Dalberto tivesse conhecido Doralda em função profissional. Pois, apesar das reiteradas manifestações de afeto de sua mulher, ele sente ciúmes de seu passado, do qual não falavam. Da comitiva de Dalberto faz parte um negro, precisamente Iládio, a quem, bastante preconceituosamente, Soropita animaliza e a quem passa a devotar um ódio inexplicado. (Depois saberemos que ele tem ciúmes terríveis de outro negro, Sabarás, então freguês de Doralda nos seus tempos de meretriz: ele parece ter deslocado seu ódio de Sabarás para Iládio.) Mas logo concluiremos que o ódio de Soropita pelo negro Iládio tem raízes que ultrapassam a individualidade de Soropita, sejam quais forem seus motivos pessoais.

É interessante que, nessa leitura estranhada e transgressiva do "Cântico dos cânticos", que é "Dãolalalão" de Guimarães Rosa, haja uma concordância com o texto base nos tópicos fundamentais do amor, da atração sexual, do afeto, da saudade, da força da figura feminina; mas uma grande discordância, que é a presença do ciúme avassalador do protagonista, relativamente à sua amada - ciúme que se vai concretizar por fim na figura do negro Iládio.

Por que Iládio? Por que ele? Doralda não tinha dormido com muitos e muitos homens, na sua profissão de prostituta? Iládio irrompe no texto à página 26 da edição que utilizamos, como um "preto", e aferido a uma codorna "preta e sangrenta" que ele matara com a espingarda: "O preto tinha espatifado a codorniz com chumbo grosso". E em seguida: "Catinga do preto e da codorniz esrasgalhada, trescalavam a léguas...". E mais adiante: “Aquele preto Iládio, com a espingarda, golias de bruto, dava um risadão, ficava para trás, em bando com o os outros".

É interessante observar que, no contexto do "Cântico dos cânticos", a cor preta da amada num determinado trecho é ressaltada. Trata-se da famosa passagem do "Nigra sum sed pulchra" ("Sou negra, mas bela"), retomada por autores vários, incluindo Palestrina, que a incorporou no libreto de sua ópera. Ressalte-se a embaraçosa adversativa: sed (mas, porém). "Sou negra, mas bela": por mais que os hermeneutas tenham se esforçado por dar conta dela, isso nos agride e decepciona. Sobretudo por causa da "explicação" da cor preta, que o próprio texto fornece: "Não olheis eu ser morena / Foi o sol que me queimou / Os filhos de minha mãe /Se voltaram contra mim, /Fazendo-me guardar as vinhas / A minha vinha, a minha... eu não a pude guardar”. Em todo o caso, em "Dãolalalão", temos uma versão pontual para essa passagem do texto bíblico, quando o narrador fala de Doralda: "Nega, ela não ficara feia, por no muito amor desusar sua virtude" (Rosa, 1965a, p.67) - em que, à maneira de Guimarães Rosa, instaura-se uma ambigüidade e retoma-se o tópos da perda da "sua vinha”, que a amada não soube guardar. 
Nos estranhamento e nas rupturas de "Dãolalalão", evoca-se a presença da cor preta nesse poema de amor com uma inversão das personagens: não é a amada, é o homem, aqui, que é o negro. E não o amado, mas um terceiro, alguém que atrairá para si o ciúme e as suspeitas do protagonista.

Para além dos fatos, para além do acontecido, porém, o negro Iládio, como já disse, povoará as fantasias do ciúme de Soropita. Ele imagina Iládio tendo relações com uma figura imaginária, uma prostituta inventada, a quem dera o nome de Izilda. Diz o narrador:

Ao ver, àquele negro Iládio, goruguto, medonho... Até o almíscar, ardido, desse, devia de estar revertendo por ali, não sendo o que aquela menina gastava em si um rio lindo de bom perfume... Ela tãozinha de bonita, simples delicada, branquinha uma princesa - e aceitando o preto Iládio, membrudo, franchão, possanço ... Ah, esse cautério! - Soropita se confrangia.

$[\ldots]$

Mas era o ferrôo de um pensamento que, que gelava, que queimava, garroso como carrapicho: o preto... Izilda entregue à natureza bronca desse negro! $\mathrm{O}$ negro não estava falando como gente, roncava e corria de mãos no chão, vindo do meio do mato, esfamiado, sujo de terra e de folhas... (ibidem, p.40)

De quem são esses pensamentos? Quem fala? O narrador? A personagem Soropita? Vemos aqui, em ação, o narrador "colado", aderido a uma das personagens. Mas o que importa é que aí o negro é animalizado: "roncava e corria de mãos no chão, vindo do meio do mato, esfamiado, sujo de terra e de folhas" - é o "macaco" das injúrias racistas - tão presente nas piadas étnicas, politicamente incorretíssimas, e, no entanto, povoando o imaginário popular, e as rodinhas de bar dos brasileiros, mestiços que somos. Pois na seqüência da fantasia de Soropita, não é mais Izilda que tem relações com Iládio:

Mas - não era Izilda, quem estava com o preto vespuço, com o Iládio ... a voz era outra: Doralda! Doralda, transtornados os olhos, arrepiada de prazeres... O preto se regalava, no forcejo daquele violo, Doralda mesma queria, até o preto mesmo se cansar, o preto não se cansava, era um bicho peludo, gorjala, do fundo do mato, dos caldeirões do inferno... (ibidem, p.40)

Registremos: aquele "violo", em contradição radical com a afirmação subseqüente, "Doralda mesma queria". Para o narrador (para Soropita?) não se tratava de uma prostituta em função profissional; era uma violação. Num padrão bem ao gosto do preconceito racial, o negro não apenas simbolizará a "sombra", o escuro dos desejos inconfessáveis, a ameaça, o perigo, mas também será apresentado como portador de uma sexualidade irreprimida e ativamente dominante. Contrariamente a Soropita, no encontro final dos dois, Iládio não trazia a espingarda: "E o preto Iládio, o negralhaz, avultado, em cima de uma besta escura. Estava sem a espingarda - para que precisava de espingarda?". Na pergunta do narrador insinua-se já seu comentário: Iládio já era portador de poderosas insígnias sexuais, não necessitaria, como Soropita, carregar vários revólveres, como descrito no início do conto. Mais uma vez, o narrador se "cola" 
à visão de uma das personagens - o que é característica do foco narrativo habitual de Guimarães Rosa, aliás. A visão de Soropita é a endossada e assumida pelo narrador, ao apresentar o negro Iládio. E isso, convenhamos, terá um potencial crítico extraordinário.

Continuo, porém, com o enredo: mesmo ao acabar por ter a impressão de que Dalberto e Doralda não se conheciam, o ciúme retrospectivo de Soropita fora reativado. Dalberto se vai, mas o negro Iládio reaparece, entre os demais companheiros do bando, saúda Soropita com seu vozeirão e um gesto de mão. Soropita acha que ele falou uma coisa "que não deu para se entender; e que seriam umas injúrias". É o que basta para que o marido de Doralda, que já tinha pedido que lhe arreassem sua montaria, o Apouco, cavalgue seu "cavalo alvo", e vá atrás do negro, a quem ele não apenas animalizará, mas demonizará: "O preto Iládio, belzebu, seu enxofre, poderoso, amontado na besta preta". E nesse encontro apocalíptico (besta negra versus cavalo branco), Soropita vai aniquilar seu adversário, que aqui agrega ao cheiro de macaco o cheiro de enxofre: "Ah, negro, vai tapar os caldeirões do inferno! Tu, preto, atrás de pobre de mulher, cheiro de macaco...". Na seqüência, o preto, que "exclamava, enorme - um grito de perdão", rola do cavalo abaixo: "Tou morto, tou morto, patrão Surrupita [...] Tomo benção ... tomo benção".

Soropita ameaça-o com o revólver, mas diante da reação de pavor e de súplica do vaqueiro, deixa-o ir, depois de moralmente aniquilado - "cobra urutu desquebrada”. Percebe-se que ao ódio provocado pelo ciúme soma-se um ódio racial - e um ódio de classe. E aqui a questão que está por detrás dessa atitude aviltante em relação ao negro se vê nomeada, apontada inequivocamente: “- Soropita comandava aquele grande escravo aos pés de seu cavalo. Igual a um pensamento mau, o preto se sumia, por mil anos. Urubus do ar comiam a fama do preto". Depois de mostrada gestualmente, pelo comportamento de Soropita em relação a Iládio, aqui, a coisa é nomeada: "aquele grande escravo".

Realmente, não houve o assassinato físico de Iládio, mas a sua degradação: "urubus do ar comiam a fama do preto". Um agudíssimo preconceito racial e a questão de classe que aí estáo embutidos: o grande escravo, aos pés de seu cavalo. Essa cena é paradigmática, e extremamente importante para o nosso conto. E é aqui, creio, que a ruptura máxima relativamente ao texto do "Cântico" se perfaz. Não apenas porque apresenta algo que não existia nesse texto bíblico, que é o ciúme - uma vez que no "Cântico" a proposta é apresentar o amor na sua perfeição, em que a separação dos amantes só se dá para acirrar a procura, a saudade e a busca ("Vistes o amado da minha alma?"); não apenas não há desconfiança ("Meu amado é meu e eu sou dele"), não há “terceiros”, não há o que possa sombrear essa relação perfeita. Mas na leitura transgressiva que do "Cântico" faz Guimarães Rosa, evidencia-se um tópos que diz respeito à "mola" da organização social brasileira, nas suas origens de corte escravista: a questão do negro, a opressão senhor/escravo, a questão da escravatura, mancha que 
subsiste na estrutura da sociedade brasileira, nas relações de classe, no convívio das pessoas, no imaginário do país.

Com efeito, em "Dãolalalão", contestando a "ausência de preconceito racial", a figura do negro é inequivocamente depositária de uma sombra no imaginário do branco, ou mesmo do mestiço como o nosso Soropita. No sertão mineiro de Guimarães Rosa, lateja algo que faz parte do solo cultural brasileiro: algo que faz parte do nexo da organização da sociedade - a herança da escravatura, a presença do negro tratado como escravo, e objeto de um racismo intenso e mal sopitado.

O narrador de Guimarães Rosa narra "objetivamente" o fato nu e bruto da hostilidade do branco contra o negro, sem comentários. Não reprova e não endossa. Apresenta os fatos, simplesmente - como se fosse tudo natural. Mas apontar é denunciar.

E aqui cabe uma reflexão: assim como na sua obra ficcional Guimarães Rosa possibilita, por exemplo, que a gente aproxime da tragédia grega esse universo do sertão, aqui também ele eleva ao nível de protagonistas de um drama de amor do mais alto quilate... um ex-matador de jagunços e uma ex-prostituta - personagens desvalidas e, no limite, marginalizadas. Mas estranhando o estranhamento, faz que uma dessas personagens exerça a mais cruel - e injusta - das opressões. Dessa maneira, questões fundamentais em que o ser humano se debate são vividos não por heróis de alta estirpe, elitizados, mas por marginalizados sertanejos. Guimarães Rosa dá estatuto de dignidade ao "homem do povo", com direito à tragédia; com direito ao páthos - o que é um fundamental traço de radicalidade ${ }^{7}$ de sua ficção.

O amor de Salomão e da Sulamita do "Cântico dos cânticos" é vivido em toda sua complexidade, contradição e ambigüidade por heróis problemáticos e degradados. Fragmentado na sua inteireza inicial, roído por ciúmes, comprometido por machismos e racismo, tingido de neurose, aqui ecoa, ressoa o amor arquetípico do Amado e da Amada. Soropita e Doralda estão mais próximos do domínio da História que do Mito, do mundo da ironia que da analogia, do "badaladal" que do sino.

Notas

1 De "A estória de Lélio e Lina" (Rosa, 1965c, p.237": “O amor era isso - lãodalalão um sino e seu badaladal".

2 Utilizo aqui a tradução da Bíblia de Jerusalém (Paulinas, 1981).

3 O "Cântico dos cânticos" foi objeto de interpretações divergentes, abrangendo várias hipóteses, que poderiam ser nucleadas em três:

Hipótese cúltica e mitológica: a origem do "Cântico" se enraizaria no culto a Ishtar e Tamuz e nos ritos de casamento divino, de hierosgamia. Esse ritual, imitado dos cananeus, teria sido praticado antigamente no culto a Iavé.

Interpretação alegórica: Javé seria o amado, e Israel a amada. Alguns místicos, como 
São João da Cruz, vêm nessa fusão apaixonada a relação da alma com Deus. A essa linhagem se filiaria o resgate operado pela alquimia.

Interpretação antropológica: podem-se buscar as origens do "Cântico" nas festas que acompanhavam a celebração do matrimônio. E nele, o amor é visto não como meio de procriação, mas como realização afetiva e sexual. Têm sido feitas comparações interessantes com as cerimônias e os cânticos nupciais dos árabes da Síria e da Palestina; e também com cânticos de amor do Egito (cf. "Introdução ao "Cântico dos cânticos", Bíblia de Jerusalém, 1981).

4 Cf. Dicionário Latim-Francês Gaffiot. Aliás, o nome Clema (e suas variações) aproximase do nome do Comprade Quelemém, de Riobaldo, que o salva do desarrazoado em que fica, por ocasião da morte de Diadorim. Quelemem = corruptela de Clemente.

5 Cf. Nota da Bíblia de Jerusalém para o termo "Sabá" (I Reis 10,1). Também em "Gênesis" (10,7) aparece Dadã ligada a Sabá.

6 E quanto a esse tópos do riso, a influência mais determinante é a grega: Afrodite é caracterizada pelo sorriso, recebendo, no "Hino Homérico", o epíteto de Philomeidés: a amiga dos sorrisos. Também as "rolinhas" e o "arrulhar dos olhos" de Doralda remetem ao animalzinho preferido da Deusa do Amor: as pombas.

7 Para o conceito de "pensamento radical", ver Candido (1995).

\section{Referências bibliográficas}

BÍBLIA de Jerusalém. São Paulo: Edições Paulinas, 1981.

BOSI, A. Situações e formas do conto brasileiro contemporâneo. In: . (Org.) Oconto brasileiro contemporâneo. Seleção de textos, introdução e notas. São Paulo: Cultrix; Editora da Universidade de São Paulo, 1975.

CANDIDO, A. O direito à literatura. In: __ Vários escritos. 3.ed. São Paulo: Duas Cidades, 1995.

MARCUSE. Eros e civilização. Rio de Janeiro: Zahar, 1968.

ROSA, J. G. Noites do sertão. Rio de Janeiro: José Olympio, 1965a.

. Buriti. In: _. Noites do sertão. Rio de Janeiro: José Olympio, 1965b.

. A estória de Lélio e Lina. In: __. No Urubuquaquá, no Pinbém. Rio de Janeiro: José Olympio, 1965c. p.237.

Correspondência com seu tradutor italiano Edoardo Bizzarri. 3.ed. Rio de Janeiro: Nova Fronteira; Editora da UFMG, 2003.

SPERBER, S. Caos e cosmos. São Paulo: Duas Cidades, 1976.

Signo e sentimento. São Paulo: Ática, 1982.

RESUMO - A novela "Dãolalalão", do livro Noites do sertão de Guimarães Rosa, mostra a presença daquilo que Northrop Frye nomeou o "Grande código" da literatura ocidental, a Bíblia, transculturada no sertão brasileiro, e as contradições daí advindas. Apontase aí, em clave de "estranhamento", a relação de um ex-jagunço e de uma ex-"militriz", aferida ao amor arquetípico de Salomão e da Sulamita, o "Amado" e a "Amada" do 
"Cântico dos cânticos" bíblico, criptografado ao longo da novela. No entanto, observese que em "Dãolalalão" comparecem também paráfrases do "Apocalipse" e referências várias a Afrodite Pandêmia, deusa do Amor no panteão grego, bem como ecos velados da prostituição sagrada, abrindo a possibilidade para uma abordagem desse tópos caro à ficção roseana, que é o amor da prostituta. Temos, concentrados nesse vértice bíblicogrego (à raiz da cultura ocidental), os elementos de uma literatura "mimetizada" - ou, mais especificamente, marcada por aquilo que é a mola da organização da sociedade brasileira: uma formação social de extração escravista.

PALAVRAS-CHAVE: "Dãolalalão", Guimarães Rosa, "Cântico dos cânticos”, Prostituição, Sociedade escravista.

ABSTRACT - The novel "Dãolalalão", from the book Nights in the backlands of Guimarães Rosa shows the presence of what Northrop Frye has called the "Great Code" of the western civilization literature, the Bible, crosscultured in the Brazilian backlands and the contradictions produced by such situation. It is shown, under the key of singularization, the relationship between an ex-jagunço and an ex-prostitute, referred to the archetypical love of Salomon and the Sulamite, the "Beloved" of the biblical "Song of songs", criptographed along the novel. However, it must be noted that in "Dãolalalão" there also occur paraphrases from the "Apocalypse" and several references to Aphrodite Pandêmos, the goddess of love in the Greek pantheon, as well as many veiled ecos of the sacred prostitution, offering an approach to a much cherished topos in the Rosean fiction, that of the prostitute's love. Concentrated in this biblical-Greek axis, which stands as roots of the western civilization, the elements of a "mimetized" literature, marked by the spring of the Brazilian social organization: its slavish background.

KErWORDS: "Dãolalalão", Guimarães Rosa, "Songs of songs", Prostitution, Slave society.

Adélia Bezerra de Meneses é doutorada em Teoria Literária e Literatura Comparada pela Universidade de São Paulo. Foi docente de Literatura Brasileira no Leitorado de Romanística da Technische Universität de Berlim, professora de Teoria Literária e Literatura Comparada na USP e na Unicamp, onde se aposentou. Atualmente, é professora colaboradora voluntária na Unicamp e orientadora em pós-graduação da USP. @ - adeliabm@terra.com.br

Artigo recebido em 8.9.2008 e aceito em 15.9.2008. 